\title{
Pelayanan Prima KBIH dan Kepuasan Jemaah Haji
}

\author{
Iis Sumiati*, Asep Muhyiddin, \& Arif Rahman \\ Jurusan Manajemen Dakwah, Fakultas Dakwah dan Komunikasi, \\ UIN Sunan Gunung Djati, Bandung \\ *Email: iiis.sumiati@student.uinsgd.ac.id
}

\begin{abstract}
ABSTRAK
Tujuan penelitian untuk mengetahui bagaimana pelayanan prima $\mathrm{KBIH}$ AlWaritsah, bagaimana kepuasan jemaah hajinya, dan bagaimana hubungan pelayanan prima KBIH Al-Waritsah terhadap kepuasan jemaah hajinya. Menurut Parasuraman, Zeithmal dan Bitner pelayanan prima harus meliputi 5 dimensi yaitu: tangibles, reliabillity, responsiveness, assurance dan emphaty.Apabila semua unsur ini terpenuhi maka tujuan perusahaan yaitu kepuasan para pelanggannya akan tercapai yang akhirnya pelanggan akan loyal terhadap perusahaan. Loyalitas pelanggan inilah yang menentukan maju mundurnya suatu perusahaan. Metode penelitian yang digunakan dalam penelitian ini adalah metode survai, Dari hasil penelitian mengenai hubungan pelayanan prima terhadap kepuasan jemaah haji yang dilakukan dan dilanjutkan dengan menganalisis data dengan menggunakan SPSS For Windows Versi 20.0, maka hasilnya adalah terdapat hubungan yang positif dan kuat antara pelayanan prima terhadap kepuasan jemaah sebesar 0,620 atau $62 \%$, berdasarkan uji determinasi diketahui bahwa pelayanan prima mempengarui kepuasan jemaah dengan tingkat pengaruh sebesar 0,720 atau 72\%. Sehingga hipotesis yang menyatakan ada hubungan antara pelayanan prima terhadap kepuasan jemaah dapat diterima. Dengan demikian dapat disimpulkan bahwa ada pengaruh positif dari pelayanan prima KBIH (Al-Waritsah) terhadap kepuasan jemaah haji.
\end{abstract}

Kata Kunci: Pelayanan Prima, KBIH, Jemaah Haji

\section{ABSTRACT}

The research objective was to find out how the $\mathrm{KBIH} A \mathrm{Al} W$ aritsah excellent service, how satisfied the pilgrims were, and how the relationship between $\mathrm{KBIH} A \mathrm{Al}-W$ aritsah's excellent service to the satisfaction of the pilgrims. According to Parasuraman, Zeithmal and Bitner excellent service must include 5 dimensions, namely: tangibles, reliabillity, responsiveness, assurance and empathy. If all these elements are fulfilled, the company's goal is the satisfaction of its customers will be achieved which ultimately customers will be loyal to the company. This customer loyalty determines the progress of a company. The research method used in this study is a survey method, from the results of research on the relationship of excellent service to the satisfaction of pilgrims conducted and continued by analyzing data using SPSS For Windows Version 20.0, the result is a positive and strong relationship between excellent service to congregation satisfaction is 0.620 
Iis Sumiati, Asep Muhyiddin, \& Arif Rahman

or $62 \%$, based on the determination test it is known that excellent service affects the satisfaction of the congregation with a level of influence of 0.720 or $72 \%$. So the bypothesis that there is a relationship between excellent service and satisfaction of the congregation can be accepted. Thus it can be concluded that there is a positive influence of the KBIH prime service (Al-Waritsah) on the satisfaction of pilgrims.

Keywords: Prime Service, KBIH, Hajj

\section{PENDAHULUAN}

Pada era globalisasi sekarang ini persaingan bisnis menjadi sangat ketat. Persaingan yang cukup ketat juga terlihat jelas dalam jasa pelayanan ibadah haji dan umroh yang diselenggarakan oleh Kelompok Bimbingan Ibadah Haji dan Umroh (KBIH). Dalam dunia usaha, salah satu hal yang tidak bisa dihindari adalah adanya persaingan. Untuk memenangkan suatu persaingan, maka perusahaan harus mampu melakukan manajerial yang tepat disemua aspek.

Namun ada beberapa hal yang harus dipahami perusahan selaku produsen yaitu memberikan kepuasan kepada pelanggan/jemaah dengan memenuhi kebutuhan, keinginan, dan harapan mereka merupakan hal yang sangat penting bagi perusahaan untuk menghadapi persaingan. Citra mereka merupakan bagian yang tidak terpisahkan dari hal-hal tersebut disamping juga pelayanan. Pelayanan sangat mempengaruhi kepuasan pelanggan/jemaah. Jika pelayanan yang dirasakan tidak sesuai dengan harapan pelanggan/jemaah maka pelanggan tidak akan puas dan hal itu secara tidak langsung akan mempengaruhi pelayanan yang dihasilkan oleh perusahaan.

Maka dari itu, strategi keberhasilan yang dilakukan oleh lembaga jasa tersebut ditentukan oleh kemampuan dalam memberikan pelayanan yang berkualitas kepada pelanggannya. Hal ini dikarenakan jamaah haji sekarang mencari lembaga yang memiliki mutu pelayanan yang baik yang dapat membimbing mereka dalam melaksanakan ibadah haji. Kualitas pelayanan yang diberikan KBIH antara lain bukti fisik, kehandalan, jaminan, daya tanggap dan perhatian.

Kelompok Bimbingan Ibadah Haji (KBIH) merupakan salah satu sarana untuk mendapatkan ilmu dan gambaran yang mendasar tentang haji dan segala permasalahannya sehingga nanti pada saat dilaksanakan tidak terjadi hal-hal yang tidak diinginkan. Dengan adanya latihan khusus tata cara/manasik haji dapat memberikan gambaran serta bagaimana mengantisipasi masalah-masalah yang timbul dalam pelaksanaan ibadah haji nantinya. Hal ini sangat penting bagi para calon jemaah haji agar mampu melaksanakan ibadah haji dengan lancar dan sah sesuai dengan tuntunan syariat Islam sehingga memperoleh haji yang mabrur. KBIH dituntut untuk memberikan pelayanan yang terbaik serta serta memberikan fasilitas yaitu kemudahan dalam pemenuhan kebutuhan dan mewujudkan kepuasan agar pelanggan selalu loyal terhadap kepuasan.

Pihak KBIH terus berupaya untuk meningkatkan kualitas pelayanannya baik dari segi pelayanan oleh pembimbing, karyawan, maupun pemimpin. Karena 
Hubungan Pelayanan Prima Kbih terhadap Kepuasan Jemaah Haji

dengan ada upaya peningkatan pelayanan diharapkan jemaah haji merasa puas sehingga dapat memberitahukan kepada orang lain tentang kualitas pelayanan yang diberikan.

Salah satu obyek penelitian yaitu Kelompok Bimbingan Ibadah Haji (KBIH) Al-Waritsah Bandung, hal ini berdasarkan izin dari Kementrian Agama Nomor 371 tentang Kelompok Bimbingan Ibadah Haji maka KBIH Al-Waritsah Bandung merupakan penyelenggaraan resmi ibadah umrah dan haji regular. Penulis menjadikan KBIH Al-Waritsah Bandung sebagai obyek penelitian karena perusahaan tersebut menerapkan manajemen berorientasi pada peningkatan mutu pelayanan. Salah satu kelebihan dari KBIH Al-Waritsah adalah transparasi keterbukaan yang berkaitan dengan keuangan, pelaksanaan manasik yang tak kurang dari 17 kali pertemuan, memiliki administrasi kantor yang tertib, kantor yang permanen yang sangat memadai bagi terlaksananya pelayanan yang terbaik, struktur pengurus yang jelas dengan segala program kerjanya dan segala hal yang bermuara pada kepuasan jama'ah. Maka tak heran bila Kementrian Agama selalu mengganjar dengan nilai setrifikasi sangat baik. Nilai-nilai pelayanan yang ada dalam KBIH Al-Waritsah ditanam sedemikian kuat oleh sang pendiri K. H Lukman Hakim, dimana baginya pelayanan terbaik adalah diatas segala-galanya dan tidak bisa ditawar-tawar atau bahkan ditukar dengan apapun.

Pelayanan KBIH telah membawa feedback yang baik yaitu berupa peningkatan jumlah jemaah yang dibimbingnya disetiap tahunnya. Semuanya merupakan imbalan dari profesionalisme dan keikhlasan beribadah dalam membimbing jemaahnya sehingga dengan sendirinya service yang memuaskan itu disampaikan kepada orang lain demikian seterusnya sehingga setiap tahunnya jemaah haji KBIH Al-Waritsah selalu meningkat. KBIH Al-Waritsah memberikan pelayanan bimbingan manasik haji setiap satu bulan sekali pada awal bulan, dan bulan selanjutnya 2 minggu sekali selama 3 bulan dan 2 bulan sebelum keberangkatan 1 minggu sekali dengan akumulasi jumlah 17 kali manasik dimulai sejak 7 bulan sebelum pemberangkatan (dilaksanakan diawal). Hal ini sangat penting untuk diketahui karena erat kaitannya dengan masalah komunikasi dari mulut ke mulut yang merupakan salah satu sarana penentu bagi jemaah haji untuk mengambil keputusan mengenai produk dan jasa yang digunakan. Sudah barang tentu jemaah haji yang merasa puas cenderung akan menyarankan rekan/keluarganya yang bermaksud menggunakan jasanya.

Dalam arti sempit pelayanan bisa diartikan sebagai upaya pemenuhan kebutuhan, maka dalam ruang lingkup yang lebih luas, menurut Gronroos, pelayanan merupakan suatu/serangkaian aktivitas yang bersifat tidak kasat mata (tidak dapat diraba) yang terjadi sebagai akibat adanya interaksi antara konsumen atau pelanggan dengan karyawan, atau hal-hal lain yang disediakan oleh pemberi layanan yang dimaksudkan untuk memecahkan masalah konsumen atau pelanggan. (Ratmanto dan Atik Septi Winarsih, 2014: 2).

Pengertian pelayanan prima merupakan terjemah dari istilah "Excellent Service" yang secara harfiah berarti pelayanan yang sangat baik dan atau pelayanan 
yang terbaik. Disebut sangat baik atau terbaik, karena sesuai dengan standar pelayanan yang berlaku atau memiliki oleh instansi yang memberikan pelayanan. Apabila instansi pelayanan belum memiliki standar pelayanan, maka pelayanan disebut sangat baik atau terbaik atau akan menjadi prima, manakala dapat atau mampu memuaskan pihak yang dilayani (pelanggan). Jadi pelayanan prima dalam hai ini sesuai dengan harapan pelanggan. Tentunya agar keprimaan suatu pelayanan dapat diukur, bagi instansi pemberi pelayanan yang belum memiliki standar pelayanan, maka perlu membuat standar pelayanan prima sesuai dengan tugas dan fungsinya.

Sementara itu yang disebut dengan konsumen atau sering disebut dengan customer, adalah masyarakat yang mendapat manfaat aktivitas yang dilakukan oleh organisasi atau petugas tersebut. Pelayanan yang dikatakan tidak berwujud tersebut berarti bahwa pelayana itu hanya dapat dirasakan (Sutopo dan Adi Suryanto, 2009: 8).

Menurut Parasuraman, Zeithmal, dan Bitner, (1996) mengatakan, pelayanan prima didasari 5 dimensi, yaitu : 1) Bukti fisik (tangible), penampakan fisik dari gedung, peralatan, pegawai, sarana komunikasi, dan fasilitas-fasilitas lain yang dimiliki oleh providers. 2) Kehandalan (reliability), kemampuan memberikan pelayanan yang dijanjikan dengan segera, akurat kehandalan dan memuaskan. 3) Daya tanggap (responsiveness), kemampuan para staff untuk membantu para pelanggan dengan memberikan pelayanan dengan tanggap (kesiapan). 4) Jaminan (assurance), pengetahuan, kemampuan, kesopanan, sifat yang dapat dipercaya yang dimiliki oleh staff (bebas dari bahaya, resiko dan keragu-raguan). 5) Empati (emphaty), kemudahan dalam melakukan hubungan, komunikasi yang baik, perhatian, dan memahami kebutuhan para pelanggan.

Dari lima dimensi pelayanan prima diatas sebagi indikator mengukur seberapa bagus kualitas suatu layana jasa, konsumen akan memliki dua persepsi akan layanan tersebut sesuai dengan teori Lewis dan Booms, (Fandy Tjiptono, 2005: 121). Persepsi tersebut yaitu pelanggan atas layanan yang nyata mereka terima (perceived service) dan layanan yang sesungguhnya diharapkan/diinginkan (exspected service). Tidak terpenuhinya antara harapan pelanggan dengan tigkat kualitas pelayanan yang diberikan oleh perusahaan atau lembaga menyebabkan kesenjangan (gap) seperti yang diungkapkan oleh Parasuraman, Zeithmal, dan Berry (Fandy Tjiptono, 2006:146).

Kepuasan Satisfaction berasal dari bahas latin, yaitu satis yang berarti enough atau cukup dan facare yang berarti to do atau melakukan (Nina Rahmayanty, 2010 : 17). Jadi produk atau jasa yang bisa memuaskan adalah produk dan jasa yang sanggup memberikan sesuatu yang dicari oleh pelanggan sampai pada tingkat cukup. Kepuasan pelanggan berbeda-beda bergantung nilai suatu produk/objektivitasnya maupun subjektivitasnya.

Day Tse dan Wilton menyatakan bahwa kepuasan atau ketidak puasan pelanggan adalah respon pelanggan terhadap evaluasi ketidaksesuaian (disconfirmation) yang dirasakan antara harapan sebelumnya (atau norma kinerja 
Hubungan Pelayanan Prima Kbih terhadap Kepuasan Jemaah Haji

lainnya) dan kinerja aktual produk yang dirasakan setelah pemakainnya (Fandy Tjiptono dan Anastasia Diana, 2003: 102)

Mengutip dari pendapat pakar pemasaran Kotler (1994) menandaskan bahwa "Kepuasan pelanggan adalah tingkat perasaan seseorang setelah membandingkan kinerja (hasil) yang dirasakan dengan harapannya" (Fandy tjiptono 2006: 146). Oleh karena itu, maka tingkat kepuasan adalah perbedaan antara kinerja yang dirasakan dengan harapan (Sutopo dan Adi Suryanto. 2009: 29). Dengan demikian apabila dikaitkan dengan pelanggan, maka pelanggan dapat merasakan hal-hal sebagai berikut : kalau kinerjanya dibawah harapan, pelanggan akan merasa kecewa, kalau kinerjanya sesuai harapan, maka pelanggan akan merasa puas, kalau kinerjanya melebihi harapan, maka pelanggan akan sangat puas.

Kelompok Bimbingan Ibadah Haji (KBIH) adalah lembaga/yayasan sosisl islam yang bergerak dibidang bimbingan manasik/ibadah haji terhadap calon jamaah/jamaah haji, baik selama dalam pembekalan di tanah air maupun pada saat pelaksanaan ibadah haji di Arab Saudi (SOP KBIH Al-Waritsah).

$\mathrm{KBIH}$ sebagai suatu lembaga sosial keagamaan yang menyelenggarakan bimbingan ibadah haji terhadap calon jamaah/jamaah haji merupakan organisasi underbow dari suatu organisasi induk (pemerintah, khususnya Departemen Agama) yang berbadan hukum dan mempunyai program kerja untuk membimbing dan membina calon jamaah/jamaah haji. Keberadaan KBIH diatur berdasarkan KMA Nomor 396 tahun 2003 tentang penyelenggaraan Ibadah Haji dan Umroh (Depag RI, 2005:1-4).

Penelitian ini dilakukan pada KBIH Al-Waritsah yang berada di Jln. Holis Gg. Haji Taofik Rt/Rw 01/11 Kamp.Seketimbang Kel.Cigondewah Kaler Kota Bandung.

Penelitian ini untuk mengetahui pelayanan prima yang dilaksanakan oleh $\mathrm{KBIH}$ Al-Waritsah, kepuasan jemaah haji terhadap pelayanan prima $\mathrm{KBIH} \mathrm{Al}-$ Waritsah, dan hubungan pelayanan prima KBIH Al-Waritsah terhadap kepuasan jemaah haji.

\section{METODE PENELITIAN}

Metode yang digunakan dalam penelitian ini adalah metode survei. Metode survei adalah metode yang dilakukan pengamatan langsung terhadap suatu gejala dalam populasi besar dan kecil. Proses penelitian survei merupakan fenomena sosial dalam bidang pendidikan yang menarik perhatian peneliti. Dengan metode penelitian tersebut, peneliti dapat mengungkapkan kejelasan hubungan antara variabel dari suatu masalah, dan jenis penelitian yang digunakan adalah jenis penelitian verifikatif karena akan memperoleh kejelasan tentang hubungan variabel dari suatu masalah dengan melakukan uji hipotesis guna mengetahui pengaruh antara variabel $\mathrm{X}$ dan variabel $\mathrm{Y}$ yang peneliti sedang amati.

Model penelitian ini menggunakan model penelitian secara kuantiatif dengan metode analisis dan angket yang berfungsi sebagai sarana pengumpulan informasi awal dari para informan yang bersedia dan berkenan ditemui. 
Iis Sumiati, Asep Muhyiddin, \& Arif Rahman

Jenis data dalam penelitian ini adalah jenis data kuantitatif, yaitu data yang berkaitan dengan perumusan masalah dan tujuan penelitian yang telah dibuat sebelumnya oleh penulis yaitu: a) Data yang berhubungan dengan pelayanan prima $\mathrm{KBIH}$ Al-Waritsah Bandung. b) Data tentang kepuasan jemaah haji KBIH AlWaritsah. c) Data tentang hubungan pelayanan prima KBIH Al-Waritsah terhadap tingkat kepuasan jemaah haji.

Sumber data yang digunakan dalam penelitian ini adalah sumber data primer dan sumber data sekunder. Data primer adalah data yang diperoleh langsung dari subyek penelitian dengan menggunakan alat pengukuran atau alat pengambilan data langsung pada subjek sebagai sumber informasi yang dicari. Data primer diperoleh dari wawancara, koesioner, observasi dan jemaah haji angkatan 2015. Data sekunder adalah data yang diperoleh dari pihak lain, tidak langsung diperoleh oleh peneliti dari subjek penelitiannya. Data sekunder dalam penelitian ini bertujuan untuk mendapatkan data tambahan sebagai penguat ini adalah data-data yang didapat dari data primer. Data sekunder dalam penelitian ini adalah Direktur KBIH Al-Waritsah, beberapa karyawan, studi kepustakaan dan studi dokumenter KBIH Al-Waritsah.

Populasi adalah wilayah generalisasi yang terdiri atas: obyek/subyek yang mempunyai kualitas dan karakteristik tertentu yang ditetapkan oleh peneliti untuk dipelajari dan kemudian ditarik kesimpulannya (Sugiyono, 2014:80). Populasi yang dimaksudkan dalam penelitian ini adalah populasi sasaran (target population) yang dibatasi pada jemaah KBIH Al-Waritsah Bandung angkatan 2015, namun tidak dibatasi oleh jenis kelamin, usia, tingkat pendidikan, dan pekerjaan. Pembatasan ini dilakukan mengingat ini adalah penelitian mengenai " Hubungan Pelayanan Prima KBIH terhadap Kepuasan Jemaah Haji”.

Suharsimi Arikunto (2006:209) mengemukakan pendapatnya bahwa yang dimaksud sample adalah sebagian atau wakil populasi yang akan diteliti. Pengambilan sampel dalam penelitian ini menggunakan probability sampling. Pada probability sampling tersebut peneliti memilih menggunakan teknik pengambilan sampel dengan cara purposive sampling yaitu teknik sampling yang digunakan oleh peneliti jika peneliti mempunyai petimbangan-pertimbangan tertentu didalam pengambilan sampelnya. Untuk menentukan jumlah sampel, peneliti menggunakan rumus yang dikembangkan oleh Taro Yamane (Rakma, 1998: 82) sebagai berikut: $n=\frac{N}{N d^{2}+1}$ berdasarkan rumus diatas, maka sampel dengan populasi sebanyak 77 orang adalah 44 orang.

Teknik pengumpulan data adalah cara-cara yang dapat digunakan untuk mengumpulkan data (Riduwan, 2009 : 37). Maka peneliti menggunakan beberapa teknik pengumpulan data diantaranya: a) Observasi adalah suatu cara untuk mengumpulkan data penelitian. Teknik ini dapat memberikan gambar kondisi yang memuaskan, artinya memberikan gambaran menyeluruh apa adanya. Observasi dilakukan untuk memperoleh data dari lapangan melalui pengamatan secara langsung terhadap objek penelitian. Penulis mengamati secara langsung terhadap objek penelitian untuk mencatat apa yang dilihat dan didengar tentang 
hal-hal yang berhubungan dengan bahan-bahan yang diperlukan. b) Wawancara adalah metode untuk mendapatkan data dengan cara melakukan tanya jawab secara langsung dengan pihak-pihak yang bersangkutan guna mendapatkan data dan keterangan yang menunjang analisis dalam penelitian. Wawancara yang dimaksudkan untuk mengumpulkan data dan informasi secara pasti berdasarkan data yang sesuai dengan tujuan peneliti. c) Metode dokumentasi adalah penyelidikan yang ditunjukan pada penguraian dan penjelasan tentang apa yang telah lalu melalui sumber-sumber dokumen. Metode ini penyusun gunakan untuk mencari data tentang catatan, transkip, buku, notulen, rapat dan lain-lain yang berkenaan tentang daftar jemaah haji serta sarana dan prasarana yang ada di KBIH Al-Waritsah Bandung. d) Angket (Koesioner) adalah teknik pengumpulan data yang dilakukan dengan cara memberi seperangkat pertanyaan tertulis kepada responden untuk dijawabnya. Koesioner ini dapat berupa pertanyaan atau pernyataan tertutup yang diberikan langsung kepada repsonden ( Sugiyono, 2011 : 142). Dalam penyebaran angket ini digunakan item-item berkala, berupa skala sikap, yaitu skala Likert meminta kepada responden sebagai individu untuk menjawab suatu pertanyaan dengan sangat setuju (SS), setuju (S), tidak berpendapat (TS), tidak setuju (TS) dan sangat tidak setuju (STS). Masing-masing jawaban dikaitkan dengan angka atau nilai (Tanierdja, 2011: 136)

Adapun langkah-langkah dalam pengujian instrumen yang akan digunakan oleh peneliti adalah sebagai berikut: 1) Uji Validitas, Arikunto (Riduwan, 2011:97) menjelaskan bahwa uji validitas adalah suatu ukuran yang menunjukan tingkat keandalan atau kesahihan suatu alat ukur. Jika instrumen dikatakan valid berarti menunjukan alat ukur yang digunakan untuk mendapatkan data itu valid sehingga valid, berarti instrumen tersebut dapat digunakan untuk mengukur apa yang seharusnya diukur. 2) Uji Reliabilitas ialah pengujian instrument untuk menentukan kehandalan atau tingkat kepercayaan alat pengungkapan dari data. Dengan diperoleh nilai $r$ dari uji validitas yang menunjukan hasil indeks korelasi yang menyatakan ada atau tidaknya hubungan antara dua belahan instrument. Setiap alat pengukur seharusnya memiliki kemampuan untuk memberikan hasil pengukuran yang relativ konsisten dari waktu ke waktu. Teknik yang digunakan untuk menguji reliabilitas dalam penelitian ini adalah teknik $A \not p h a$ Cronbach's. Alpha Cronbach's adalah teknik pengujian data dengan melihat hasil alpha yang dihasilkan. Perhitungan uji reliabilitas ini akan dilakukan menggunakan Software SPSS versi 20.0 For Windows.

\section{HASIL DAN PEMBAHASAN}

Munculnya kelompok bimbingan Ibadah Haji (KBIH) dengan nama "AlWaritsah" yang berada dibawah naungan Yayasan Pondok Pesantren Al-Waritsah Bandung adalah bermula dari Kiyai H. Lukman Hakim yang waktu itu beliau berangkat ke tanah suci untuk melaksanakan ibadah haji, setelah beberapa kali berangkat ada beberapa dari jemaahnya ingin melaksanakan haji akan tetapi tidak 
Iis Sumiati, Asep Muhyiddin, \& Arif Rahman

berani untuk berangkat dikarnakan tidak mengetahui secara rinci bangaimana pelaksanaan ibadah haji. Maka dari itu dengan dukungan dari jamaahnya dan respon yang baik dari masyarakat kiyai haji mendirikan $\mathrm{KBIH}$ dengan nama " $\mathrm{Al}$ Waritsah"

KBIH Al-Waritsah didirikan pada tahun 2004 yang berada dalam naungan Yayasan Pondok Pesantren Al-Waritsah yang letaknya di Jl. Holis gg. H Taofik Rt/Rw 01/11 Kmp. Seketimbang Kel. Cigondewah Kaler Kec. Babakan Ciparay Kota Bandung, menjalankan aktifitasnya berdasarkan Surat Keputusan (SK) Kepala Kantor wilayah Departemen Agama Kota Bandung Nomor : KD. 10.19 /5/HJ.00/444.e/2014 tanggal 18 Februari 2014.

Pada saat itu KBIH Al-Waritsah sudah memiliki jemaah yang akan berangkat haji yang berjumlah 26 orang, dikarnakan pada tahun itu pemerintah tidak sedang mengeluarkan Surat Izin Oprasional untuk KBIH sehingga jemaah KBIH A-Waritsah mengikuti KBIH lain untuk sementara waktu. Namun pada tahun 2013 sudah mandiri dikarnakan sudah mendapat izin opasional dari Kemenag.

Dalam memuaskan jemaah haji KBIH Al-Waritsah terus meningkatkan pelayanan yang baik. Salah satunya dengan memberikan pelayanan yang unggul, yaitu pelayanan yang diberikan KBIH kepada jemaah melalui : a) Pemrosesan administrasi haji. b) Test kesehatan calon jemaah haji. c) Bimbingan manasik haji. c) Zikir akbar (istigosah)/pengajian tiap bulannya.

KBIH Al-Waritsah bekerja sama dengan pihak-pihak bank syari'ah dalam memudahkan calon jemaah haji untuk menyimpan dana dan membantu calon jemaah haji dalam proses administasi pembuatan tabungan baru karena tidak semua calon jemaah haji memiliki tabungan syariah.

Adapun diferensasi atau pembeda yang ditawarkan KBIH Al-Waritsah pada jemaahnya adalah pelayanan bimbingan dengan profesionalitas dan berazaskan keikhlasan beribadah serta kekeluargaan sehingga dengaan menggunakan pendekatan ini jemaah merasa lebih dari sekedar mendapat bimbingan tetapi juga kenyamanan dan kemudahan dalam beribadah dikarnakan segenap bantuan dan bimbingan yang diberikan oleh KBIH Al-Waritsah disamping itu jelas bahwa tarif bimbingan juga masuk kategori murah, jemaah sudah mendapatkan fasilitas cukup memadai. Begitu halnya dengan konteks yang ditawarkan KBIH Al-Waritsah berupa manasik (Pelatihan haji) selama 6 bulan dengan 17 kali pertemuan manasik dimulai sejak setahun sebelum pemberangkatan (dilaksanakan diawal bulan), hal ini tentunya sangat memudahkan jemaah untuk megikutinya dan ada tenggang waktu yang cukup untuk mempelajari sendiri di rumah. Ditambah lagi model bimbingan dengan pendekatan person to person (Perseorangan) membuat jemaah merasa diringankan bebannya dan benar-benar terbimbing.

Tenanga tim pembimbing KBIH Al-Waritsah semuanya memiliki pengalaman dan pengetahuan yang sangat cukup untuk membantu dan membimbing jemaah, serta adanya tokoh kiyai yang low profile dan disegani oleh jemaah yang sangat antusias untuk membantu kebutuhan jemaah barik secara 
Hubungan Pelayanan Prima Kbih terhadap Kepuasan Jemaah Haji

moral, spiritual dan tidak jarang terkatik dengan masalah material. Satu hal yang ditekankan oleh pengelola KBIH Al-Waritsah bahwa membimbing jemaah haji adalah sama dengan merawat bayi yang mana didalamnya dibutuhkan kesungguhan dan keikhlasan yang sangat tinggi karena hanya dengan cara yang demikian pelayanan dan membantu jamaah terasa lebih mudah dan mengenagkan.

Dalam praktiknya KBIH Al-Waritsah tidak pernah melanggar ketentuan dari Departeman Agaman karena bagaimanapun juga KBIH adalah sebuah wadah bimbingan haji dibawah naungan Departemen Agama yang didalamnya terdapat aturan-aturan yang harus dipatuhi. Adapun proses pemasarannya (iklan) $\mathrm{KBIH}$ Al-Waritsah hanya menggunakan metode word of mouth "dari mulut ke mulut" semuanya merupakan imbalan dari profesionalisme dan keikhlasan beribadah dalam membimbing jamaahnya sehingga dengan sendirinya service yang memuaskan itu disampaikan kepada orang lain demikian seterusnya sehingga setiap tahunnya jamaah KBIH Al-Waritsah selalu dan dengan jumlah cukup banyak.

Untuk mempermudah medeskripsikan data dalam penelitian ini, langkah pertama peneliti menyusun data variabel X (Pelayanan Prima) yang diperoleh melalui perhitungan rata-rata skor jawaban responden. Variabel Pelayana Prima ini diukur dengan indikator-indikator yang dijelaskan oleh Parasuraman, Zeithmal dan Bitner yaitu menjelaskan 5 unsur/dimensi yang menjadi tolak ukur Pelayanan Prima, yaitu unsur tangibles (bukti fisik), reliability (kehandalan), responsioness (daya tanggap), assurance (jaminan) dan emphaty (perhatian). Variabel Pelayanan Prima ini diukur melalui 44 item pertanyaan, kuesioner ini disebarkan kepada 44 responden.

Unsur/dimensi Tangibles terdiri dari 11 indikator atau pertanyaan yang disebarkan kepada responden. Berikut ini merupakan uraian-uraian indikator dari ukuran yang berkaitan dengan unsur/dimensi tangibles (bukti fisik).

Pertanyaan pertama adalah lokasi gedung atau tempat yang strategis. Berdasarkan hasil perhitungan diketahui bahwa nilai rata-rata untuk tingkat ukuran lokasi gedung atau tempat sebesar 80,45\%. Pertanyaan kedua yaitu ketersediaan ruang tunggu yang memadai. Skor rata-rata untuk tingkat ukuran ruang tunggu yang memadai yang disediakan oleh KBIH Al-Waritsah sebesar 74,54\%. Pertanyaan ketiga yaitu ketersediaan tempat parkir yang luas. Skor rata-rata untuk tingkat ukuran tempat parkir yang disediakan oleh KBIH Al-Waritsah sebesar 76,36\%. Pertanyaan keempat yaitu ketersediaan tempat manasik/bimbingan yang sesuai dengan kapasitas jamaah. Skor rata-rata untuk tingkat ukuran tempat manasik/bimbingan yang diberikan oleh KBIH Al-Waritsah sebesar 77,27\%. Pertanyaan kelima indikator tangible yaitu kelengkapan fasilitas yang menyangkut ibadah haji. Skor rata-rata untuk tingkat ukuran kelengkapan fasilitas yang menyangkut ibadah haji sebesar 79,09\%. Pertanyaan keenam indikator tangible yaitu penguasaan materi manasik oleh pembimbing. Skor rata-rata untuk tingkat ukuran penguasaan materi manasik pembimbing ibadah haji sebesar 83,63\%. Pertanyaan ketujuh indikator tangible yaitu kesesuaian matei manasik dengan sunah Rasul. Skor rata-rata untuk tingkat ukuran matei manasik yang disampaikan sesuai 
Iis Sumiati, Asep Muhyiddin, \& Arif Rahman

dengan sunah Rasul sebesar 84,09\%. Pertanyaan kedelapan indikator tangible yaitu penyampaian matei manasik yang mudah dipahamai. Skor rata-rata untuk tingkat ukuran penyampaian matei oleh pembimbing yang mudah dipahami sebesar $85,5 \%$. Pertanyaan kesembilan indikator tangible yaitu kerapihan penampilan petugas/karyawan. Skor rata-rata untuk tingkat ukuran kerapihan penampilan petugas/karyawan KBIH Al-Waritsah sebesar 80,90\%. Pertanyaan kesepuluh indikator tangible yaitu kebersihan ruangan tempat kegiatan. Skor rata-rata untuk tingkat ukuran kebersihan ruangan tempat kegiatan sebesar 83,18\%. Pertanyaan kesebelas indikator tangible yaitu kelengkapan inventaris. Skor rata-rata untuk ukuran kelengkapan inventaris $\mathrm{KBIH}$ Al-Waritsah sebesar 75\%. Jumlah nilai ratarata keseluruhan indikator tangibles adalah 80,07\%. Apabila dikonsultasikan dengan skala interpretasi skor rata-rata jawaban responden, maka presentasi tersebut berada pada rentang 61\%-80\% atau berada pada tingkat kuat. Dengan demikian dapat disimpulkan bahwa pelayanan KBIH Al-Waritsah dilihat dari indikator tangibles menurut penelitian para jemaah adalah tinggi/baik.

Unsur/dimensi reliabillity ini terdiri dari 9 indikator atau pertanyaan yang disebarkan kepada 44 responden. Berikut ini merupakan uraian-uraian indikator dari ukuran yang berkaitan dengan unsur kehandalan (reliabillity). Pertanyaan pertama indikator reliabillity adalah prosedur penerimaan jemaah haji dilayani dengan cepat dan tidak berbelit-belit. Berdasarkan hasil perhitungan diketahui bahwa nilai rata-rata untuk tingkat ukuran prosedur penerimaan jemaah haji yang dilayani dengan cepat dan tidak berbelit-belit sebesar 82,27\%. Pertanyaan kedua indikator reliabillity adalah kesesuaian biaya yang dikeluarkan dengan biaya yang ditawarkan. Berdasarkan hasil perhitungan diketahui bahwa nilai rata-rata untuk tingkat ukuran kesesuaian biaya yang dikeluarkan dengan yang ditawarkan KBIH Al-Waritsah sebesar 83,63\%. Pertanyaan ketiga indikator reliability yaitu kesesuaian materi manasik dengan praktek ibadah haji di Mekkah. Skor rata-rata untuk tingkat ukuran kesesuaian materi manasik dengan praktik ibadah haji di Mekkah sebesar $81,81 \%$. Pertanyaan keempat indikator reliability yaitu ketepatan waktu saat memberikan pelayanan ibadah haji (seperti manasik). Skor rata-rata untuk tingkat ukuran ketepatan waktu saat memberikan pelayanan sebesar $80 \%$. Pertanyaan kelima indikator reliability yaitu kesesuaian pelaksanaan pelayanan dengan yang dijanjikan. Skor rata-rata kesesuaian pelaksanaan pelayanan yang dijanjikan oleh KBIH Al-Waritsah sebesar 80,45\%. Pertanyaan keenam indikator reliability yaitu keakuratan informasi tentang perkembangani ibadah haji. Skor rata-rata untuk tingkat ukuran keakuratan informasi tentang perkembangan ibadah haji yang diberikan oleh KBIH Al-Waritsah sebesar 79,54\%. Pertanyaan ketujuh indikator reliability yaitu intensitas penyampaian informasi ibadah haji. Skor rata-rata untuk tingkat ukuran intensitas penyampaian informasi tentang perkembangan ibadah haji sebesar 83,18\%. Pertanyaan kedelapan indikator reliability kesigapan pembimbing dalam melayani jemaah haji. Skor rata-rata untuk tingkat ukuran kesigapan pembimbing dalam melayani jemaah haji sebesar 80,45\%. Pertanyaan kesembilan indikator reliability Karyawan/petugas selalu memperhatikan keluhan 
Hubungan Pelayanan Prima Kbih terhadap Kepuasan Jemaah Haji

jemaah haji. Skor rata-rata untuk tingkat ukuran karyawan/petugas selalu memperhatikan keluhan jemaah haji sebesar $82,27 \%$. Jumlah nilai rata-rata keseluruhan indikator reliability adalah 81,51\%. Apabila dikonsultasikan dengan skala interpretasi skor rata-rata jawaban responden, maka presentasi tersebut berada pada rentang $81 \%-100 \%$ atau berada pada tingkat sangat kuat. Dengan demikian dapat disimpulkan bahawa pelayanan $\mathrm{KBIH}$ Al-Waritsah dilihat dari indikator reliability menurut penilaian jemaah adalah tinggi/baik.

Pada unsur/dimensi responsiveness ini terdiri dari 8 indikator atau pertanyaan yang disebarkan kepada 44 responden. Berikut ini merupakan uraian-uraian indikator dari ukuran yang berkaitan dengan unsur daya tanggap (responsiveness). Pertanyaan pertama indikator responsiveness adalah kecepatan petugas/karyawan dalam memberikan pelayanan. Berdasarkan hasil perhitungan diketahui bahwa nilai rata-rata untuk tingkat ukuran kecepatan petugas/karyawan $\mathrm{KBIH}$ AlWaritsah dalam memberikan pelayanan sebesar 79,09\%. Pertanyaan kedua indikator responsiveness yaitu kesigapan petugas/ karyawan dalam membantu jamaah. Skor rata-rata untuk tingkat ukuran kesigapan petugas/karyawan KBIH Al-Waritsah untuk membantu jemaah adalah sebesar 80,90\%. Pertanyaan ketiga indikator responsiveness yaitu kecepatan petugas / karyawan dalam menagani keluhan jamaah. Skor rata-rata untuk tingkat ukuran kecepatan petugas/karyawan KBIH Al-Waritsah dalam penanganan keluhan jemaah sebesar $81,81 \%$. Pertanyaan keempat indikator responsiveness yaitu kesesuian pemenuhan kebutuhan jemaah. Skor rata-rata untuk tingkat ukuran kesesuaian pemenuhan kebutuhan diberikan oleh KBIH Al-Waritsah kepada jemaah sebesar 79,09\%. Pertanyaan kelima indikator responsiveness yaitu ketuntasan petugas/karyawan dalam mengatasi keluhan jamaah. Skor rata-rata untuk tingkat ukuran ketuntasan peugas/karyawan KBIH Al-Waritsah dalam mengatasi keluhan jemaah sebesar 79,09\%. Pertanyaan keenam indikator responsiveness yaitu pembimbing memberikan kesempatan bertanya kepada jemaah haji. Skor rata-rata untuk tingkat ukuran pembimbing memberikan kesempatan bertanya kepada jemaah haji sebesar $80,90 \%$. Pertanyaan ketujuh indikator responsiveness yaitu karyawan/pembimbing bersikap ramah dan sopan. Skor rata-rata untuk tingkat ukuran karyawan/pembimbing bersikap ramah dan sopan sebesar $80 \%$. Pertanyaan kedelapan indikator responsiveness yaitu pembimbing memperhatikan kebutuhan jemaah haji. Skor rata-rata untuk tingkat ukuran pembimbing memperhatikan kebutuhan jemaah haji $80 \%$. Jumlah nilai rata-rata keseluruhan indikator responsiveness adalah 80,11\%. Apabila dikonsultasikan dengan skala interpretasi skor rata-rata jawaban responden, maka presentasi tersebut berada pada rentang $61 \%-80 \%$ atau berada pada tingkat kuat. Dengan demikian dapat disimpulkan bahawa pelayanan KBIH Al-Waritsah dilihat dari indikator responsiveness menurut penilaian jemaah adalah tinggi/baik.

Pada unsur/dimensi assurance ini terdiri dari 7 indikator atau pertanyaan yang disebarkan kepada 44 responden. Berikut ini merupakan uraian-uraian indikator dari ukuran yang berkaitan dengan unsur jaminan (assurance). Pertanyaaan pertama indikator assurance yaitu keamanana jemaah saat menerima layanan. Berdasarkan 
Iis Sumiati, Asep Muhyiddin, \& Arif Rahman

hasil perhitungan diketahui bahwa niali rata-rata untuk tingkat ukuran keamanan saat jemaah menerima pelayanan yang diberikan KBIH Al-Waritsah sebesar $82,27 \%$. Pertanyaan kedua indikator assurance yaitu kenyamanan jemaah saat menerima layanan. Berdasarkan hasil perhitungan diketahui bahwa niali rata-rata untuk tingkat ukuran kenyamanan jemaah saat menerima pelayanan yang diberikan KBIH Al-Waritsah sebesar 86,81\%. Pertanyaan ketiga indikator assurance yaitu kesantunan petugas/karyawan dalam memberikan pelayanan. Berdasarkan hasil perhitungan diketahui bahwa niali rata-rata untuk tingkat ukuran kesantunan petugas/karyawan dalam memberikan pelayanan yang diberikan $\mathrm{KBIH}$ AlWaritsah sebesar $87,72 \%$. Pertanyaan keempat indikator assurance yaitu kelengkapan pengtahuan petugas/karyawan untuk menjawab pertanyaan jemaah. Skor rata-rata untuk tingkat ukuran kelengkapan pengetahuan petugas/karyawan KBIH Al-Waritsah menjawab pertanyaan jemaah sebesar 83,18\%. Pertanyaan kelima indikator assurance yaitu kemampuan petugas/karyawan dalam membantu jamaah. Adapun skor rata-rata untuk tingkat ukuran kemampuan karyawan dalam membantu jemaah sebesar $83,63 \%$. Pertanyaan keenam indikator assurance yaitu petugas/karyawan terdidik dan mampu melayani jemaah. Adapun skor rata-rata untuk tingkat ukuran petugas/karyawan terdidik dan mampu melayani jemaah sebesar $81,36 \%$. Pertanyaan terakhir indikator assurance yaitu prilaku petugas menimbulkan rasa aman. Adapun skor rata-rata untuk tingkat ukuran prilaku petugas/karyawan memberikan rasa aman sebesar $81,81 \%$. Jumlah nilai rata-rata keseluruhan indikator assurance adalah 83,82\%. Apabila dikonsultasikan dengan skala interpretasi skor rata-rata jawaban responden, maka presentasi tersebut berada pada rentang $81 \%-100 \%$ atau berada pada tingkat sangat kuat. Dengan demikian dapat disimpulkan bahawa pelayann KBIH Al-Waritsah dilihat dari indikator assurance menurut penilaian jemaah adalah sangat tinggi/baik.

Pada Unsur/dimensi emphaty ini terdiri dari 5 indikator atau pernyataan yang disebarkan kepada 44 responden. Berikut ini merupakan uraian-uraian indikator dan ukuran yang berkaitan dengan dengan unsur assurance (jaminan). Pertanyaan pertama indikator emphaty adalah keramahan sikap petugas/karyawan dalam memberikan pelayanan. Berdasarkan hasil perhitungan diketahui bahwa nilai rata-rata untuk tingkat ukuran keramahan sikap petugas/karyawan KBIH AlWaritsah dalam memberikan pelayanan sebesar $85 \%$. Pertanyaan kedua indikator emphaty adalah kemampuan petugas/karyawan dalam berkomunikasi yang baik. Skor rata-rata untuk tingkat ukuran kemampuan petugas/karyawan dalam berkomunikasi dengan baik sebesar $83,18 \%$. Pertanyaan ketiga indikator emphaty yaitu kemudahan petugas/karyawan saat dihubungi. Skor rata-rata untuk tingkat ukuran kemudahan petugas/karyawan KBIH Al-Waritsah saat dihubungi sebesar $84,54 \%$. Pertanyaan keempat indikator emphaty yaitu perhatian petugas/karyawan kepada setiap jemaah. Skor rata-rata untuk ukuran perhatian petugas/karyawan KBIH Al-Waritsah kepada setiap jemaah sebesar 82,72\%. Pertanyaan terakhir indikator emphaty yaitu petugas/karyawan memenuhi kebutuhan jemaah. Skor ratarata untuk ukuran petugas/karyawan $\mathrm{KBIH} \mathrm{Al-Waritsah} \mathrm{untuk} \mathrm{memenuhi} \mathrm{setiap}$ 
Hubungan Pelayanan Prima Kbih terhadap Kepuasan Jemaah Haji

kebutuhan jemaah sebesar 81,36\%. Jumlah nilai rata-rata keseluruhan indikator emphaty adalah 83,36\%. Apabila dikonsultasikan dengan skala interpretasi skor rata-rata jawaban responden, maka presentasi tersebut berada pada rentang $81 \%$ 100\% atau berada pada tingkat kuat. Dengan demikian dapat disimpulkan bahwa pelayanan $\mathrm{KBIH}$ Al-Waritsah dilihat dari indikator embaty menurut penilaian jemaah adalah sangat tinggi/baik.

Berdasarkan hasil penghimpunan dan analisis data yang diperoleh dari penyebaran angket kepada 44 responden/jemaah mengenai pelayanan prima pada $\mathrm{KBIH}$ Al-Waritsah yang diukur berdasarkan penilaian rata-rata dari unsur : tangibles, reliability, responsiveness, assurance dan emphaty, sebesar 81,47\%. Apabila ditafsirkan kedalam tabel keriteria interpretasi skor berada pada rentang $81 \%$ 100\% atau termasuk pada kategori sangat tinggi.

Berdasarkan penelitian yang telah dilakukan, ditinjau dari indikator pelayanan prima ditemukan bahwa umumnya pelayanan prima KBIH Al-Waritsah sudah tinggi/baik, namun tetap harus ditingkatkan lagi untuk kemajuan $\mathrm{KBIH} \mathrm{Al-}$ Waritsah kedepannya.

\section{Kepuasan Pelanggan (Jemaah) KBIH Al-Waritsah}

Untuk mempermudah mendeskripsikan data dalam penelitian ini, langkah pertama peneliti menyusun data variabel Y (Kepuasan Pelanggan) yang diperoleh melalui perhitungan rata-rata skor jawaban responden dari setiap indikator.

Variabel Kepuasan Pelanggan ini di ukur melalui 5 item pertanyaan, kuesioner ini disebarkan kepada 44 responden. Hasil dari penyebaran kuesioner ini bisa dilihat pada tabel-tabel yang akan dijelaskan dibawah ini.

Pertanyaan pertama indikator Kepuasan pelanggan yaitu Kesedian mengembangkan hubungan dengan KBIH Al-Waritsah, berdasarkan hasil perhitungan diketahui bahwa niali rata-rata untuk tingkat ukuran Kesedian mengembangkan hubungan dengan KBIH Al-Waritsah sebesar 73,18\%. Apabila dikonsultasikan dengan skala interpretasi skor rata-rata jawaban dengan 44 responden, maka presentasi tersebut berada pada rentang 61\%-80\% atau berada pada tingkat kuat/tinggi. Dengan demikian dapat disimpulkan jemaah puas atas pelayaanan yang diberikan oleh perusahaan dan bersedia megembangkan hubungan dengan perusahaan (KBIH Al-Waritsah).

Pertanyaan kedua indikator kepuasan pelanggan yaitu Kesediaan menggunakan kembali jasa KBIH Al-Waritsah, berdasarkan hasil perhitungan diketahui bahwa niali rata-rata untuk tingkat ukuran Kesediaan menggunakan kembali jasa KBIH Al-Waritsah sebesar 80,45\%. Apabila dikonsultasikan dengan skala interpretasi skor rata-rata jawaban dengan 44 responden, maka presentasi tersebut berada pada rentang 61\%-80\% atau berada pada tingkat kuat/tinggi. Dengan demikian dapat disimpulkan bahwa pelayanan KBIH Al-Waritsah baik, sehingga jemaah bersedia menggunakan kembali jasa KBIH Al-Waritsah pada kesempatan yang akan datang.

Pertanyaan ketiga indikator kepuasan pelanggan yaitu Kesediaan untuk tidak berpaling pada KBIH lain, berdasarkan hasil perhitungan diketahui bahwa niali 
Iis Sumiati, Asep Muhyiddin, \& Arif Rahman

rata-rata untuk tingkat ukuran Kesediaan untuk tidak berpaling pada KBIH lain sebesar $71,81 \%$. Apabila dikonsultasikan dengan skala interpretasi skor rata-rata jawaban dengan 44 responden, maka presentasi tersebut berada pada rentang 61\%-80\% atau berada pada tingkat kuat/tinggi. Dengan demikian dapat disimpulkan bahwa jemaah bersedia untuk tidak berpaling kepada KBIH lain, hal ini disebabkan karena jemaah merasa puas atas pelayanan yang diberikan oleh KBIH Al-Waritsah.

Pertanyaan keempat indikator Kesediaan merekomendasikan $\mathrm{KBIH}$ AlWaritsah kepada orang lain, berdasarkan hasil perhitungan diketahui bahwa niali rata-rata untuk tingkat ukuran Kesediaan merekomendasikan KBIH Al-Waritsah kepada orang lain sebesar 79,09\%. Apabila dikonsultasikan dengan skala interpretasi skor rata-rata jawaban dengan 44 responden, maka presentasi tersebut berada pada rentang $61 \%-80 \%$ atau berada pada tingkat kuat/tinggi. Dengan demikian dapat disimpulkan bahwa jemaah merasa puas dan sebagai wujud dari kepuasan jemaah yaitu jemaah bersedia merekomendasikan KBIH Al-Waritsah kepada orang lain seperti saudara, teman atau pun orang yang jemaah kenal.

Adapun pertanyaan terakhir indikator Kepuasan pelanggan yaitu Ketertarikan menggunakan jasa lain dari KBIH Al-Waritsah, berdasarkan hasil perhitungan diketahui bahwa niali rata-rata untuk tingkat ukuran Ketertarikan menggunakan jasa lain dari KBIH Al-Waritsah sebesar 76,81\%. Apabila dikonsultasikan dengan skala interpretasi skor rata-rata jawaban dengan 44 responden, maka presentasi tersebut berada pada rentang 61\%-80\% atau berada pada tingkat kuat/tinggi. Dengan demikian dapat ketika suatu perusahaan $(\mathrm{KBIH})$ memberikan pelayanan terbaiknya kepada pelanggan (jemaah) maka jemaah akan senang terhadap perusahaan tesebut, dan ketika perusahaan tersebut memiliki produk atau jasa lain dari perusahaan tersebut.

Jumlah nilai rata-rata keseluruhan indikator kepuasan pelanggan adalah $76,26 \%$. Apabila dikonsultasikan dengan skala interpretasi skor rata-rata jawaban responden, maka presentasi tersebut berada pada rentang 61\%-80 atau berada pada tingkat kuat. Dengan demikian dapat disimpulkan bahwa jawaban jemaah $\mathrm{KBIH}$ Al-Waritsah merasakan kepuasan yang tinggi.

Berdasarkan hasil penghimpunan dan analisis data yang diperoleh dari penyebaran angket kepada 44 responden/jemaah mengenai kepuasan pelanggan (jemaah) pada KBIH Al-Waritsah yang diukur berdasarkan penilaian rata-rata jawaban responden terhadap variabel kepuasan pelanggan (jemaah) yang terdiri dari indikator: kesediaan jemaah untuk menggembangkan hubungan dengan $\mathrm{KBIH}$ Al-Waritsah, kesedian jemaah menggunakan kembali jasa $\mathrm{KBIH}$ AlWaritsah, kesedian jemaah untuk tidak berpaling pada KBIH lain, kesediaan jemaah untuk merekomendasikan KBIH Al-Waritsah kepada orang lain dan kesediaan jemaah untuk menggunakan jasa lain ari $\mathrm{KBIH}$ Al-Waritsah sebesar $76,26 \%$. Apabila ditafsirkan kedalam tabel keriteria interpretasi skor berada pada rentang 61\%-80\% atau termasuk pada kategori tinggi.

Dengan demikian, hasil perhitungan data tersebut menunjukan bahwa 
Hubungan Pelayanan Prima Kbih terhadap Kepuasan Jemaah Haji

respon atau kepuasan pelanggan (jemaah) atas pelayanan yang diberikan oleh $\mathrm{KBIH}$ Al-Waritsah dikatakan tinggi.

\section{Hubungan Pelayana Prima KBIH Al-Waritsah terhadap Kepuasan Jemaah Haji}

Kepuasan merupakan unsur yang paling penting dalam perusahaan jasa. Kualitas pelayanan yang baik akan menciptakan kepuasan pelanggan secara positif. Kepuasan pelanggan bergantung pada interaksi positif pada dimensi kualitas pelayanan (pelayanan prima) yaitu tangibles, reliability, responsiveness, assurance dan emphati.

$\mathrm{KBIH}$ Al-Waritsah dituntut untuk memberikan pelayanan yang maksimal kepada jemaah, hal ini sangat diperlukan untuk meningkatkan kepuasan kepada jemaah. karena pelayanan yang prima akan berpengaruh terhadap tingkat kepuasan jemaah, sehingga jemaah tetap loyal terhadap KBIH Al-Waritsah. Bentuk loyalitas jemaah kepada KBIH Al-Waritsah itu meliputi: kesedian jemaah untuk mengembangkan hubungan dengan KBIH Al-Waritsah, kesediaan jemaah menggunakan kembali jasa KBIH Al-Waritsah, kesediaan jemaah untuk tidak berpaling pada $\mathrm{KBIH}$ alin, kesedian jemaah untuk merekomendasikan $\mathrm{KBIH} \mathrm{Al}$ Waritsah kepada orang lain dan kesediaan jemaah untuk menggunakan jasa lain. Unsur ini yang sangat dibutuhkan oleh setiap perusahaan dari para pelanggannya.

Untuk mengetahui hubungan serta memprediksi varabel X (Pelayanan Prima) terhadap variabel Y (Kepuasan Pelanggan) peneliti mencari persamaan regresi karena peneliti ingin mengetahui jawaban dari permasalahan yang diajukan dalam penelitian. Setelah melakukan perhitungan dengan menggunakan SPSS For Windows Versi 20.0, maka diperoleh nilai $=151,530+0,599$ berdasarkan nilai tersebut dapat diartikan bahwa pelayanan prima KBIH Al-Waritsah memiliki nilai 151,530. Jika pelayanan KBIH Al-Waritsah kurang bahkan tidak baik atau tidak memenuhi unsur-unsur/dimensi pelayanan prima. Tetapi jika pelayanan KBIH Al-Waritsah yang diberikan kepada jemaah baik dan memenuhi unsur dimensi pelayanan prima maka pelayanan prima $\mathrm{KBIH}$ Al-Waritsah akan meningkat sebesar 0,599 .

Berdasarkan uraian diatas dapat disimpulkan jika terdapat peningkatan pada variabel X (pelayanan prima) maka akan terjadi pula peningkatan kepuasan pelanggan sebesar 0,599 (5,99\%) perubahan ini menunjukan peningkatan, karena nilai b bertanda positif yaitu 0,599 .

Berdasarkan perhitungan koefisiensi korelasi product moment diperoleh nilai sebesar 0,620, nilai tersebut berada pada kategori yang kuat. Dengan demikian dapat disimpulkan bahwa pelayanan prima $\mathrm{KBIH}$ Al-Waritsah mempunyai pengaruh yang positif terhadap kepuasan jemaah, yaitu pengaruh yang kuat.

Adapun untuk perhitungan dengan teknik analisis koefisiensi determinasi diperoleh hasil sebesar 0,720 atau $72,0 \%$. Artinya variabel independen yaitu pelayanan prima dapat menenrangkan variabel dependent yaitu kepuasan jemaah haji sebesar 72,0\%. Sedangkan sisanya sebesar 28,0\% diterangkan oleh variabel lain yang tidak dimasukan dalam model regresi pada penelitian ini. 
Iis Sumiati, Asep Muhyiddin, \& Arif Rahman

Dengan demikian dapat disimpulkan bahwa pelayanan prima $\mathrm{KBIH}$ AlWaritsah mempunyai pengaruh yang signifikan, dengan tingkat yang kuat yang menunjukan bahwa jika pelayanan KBIH Al-Waritsah prima maka kepuasan jemaah akan tinggi. Sehingga untuk mencapi kepuasan jemaah sebagai tujuan utama perusahaan jasa maka KBIH Al-Waritsah harus memberikan pelayanan yang prima. Semakin prima pelayanan yang diberikan maka akan semakin tinggi pula kepuasan yang dirasakan pelanggan (jemaah).

Parasuraman, Zeithmal dan Berry (Tjiptono 2005: 122-123, menyatakan bahwa "Tidak terpenuhinya antara harapan pelanggan dengan kualitas pelanggan yang diberikan oleh perusahaan dapat memenuhi kepuasan pelanggan".

\section{PENUTUP}

Berdasarkan hasil penelitian yang telah dilakukan untuk mengetahui Hubungan Pelayanan Prima KBIH Terhadap Kepuasan Jemaah Haji di KBIH Al-Waritsah angkatan 2015, maka dapat disimpulkan sebagai berikut: 1) Pelayanan prima $\mathrm{KBIH}$ Al-Waritsah yang dinilai berdasarkan unsur tangibles, reliability, responsiveness, assurance dan emphaty masuk kepada kategori tinggi/baik. 2) Tingkat kepuasan pelanggan (jemaah) pada KBIH Al-Waritsah yang meliputi indikator: kesedian jemaah untuk mengembangkan hubungan dengan KBIH Al-Waritsah, kesediaan jemaah untuk untuk menggunakan kembali jasa KBIH Al-Waritsah, kesediaan jemaah untuk tidak berpaling pada KBIH lain, kesediaan jemaah untuk merekomendasikan KBIH Al-Waritsah kepada orang lain dan kesediaan jemaah untuk menggunakan jasa lain yang ada diberikan oleh KBIH Al-Waritsah. 3) Hasil penelitian mengenai hubungan pelayanan prima terhadap kepuasan jemaah (pelanggan) pada KBIH Al-Waritsah, diperoleh kesimpulan bahwa pelayanan prima KBIH Al-Waritsah berpengaruh positif dan signifikan terhadap kepuasa jemaah. Hal ini didasarkan pada hasil perhitungan analisis kedua variabel dengan menggunakan SPSS For Windows Versi 20.0 tingkat korelasi antara varabel tangibles, reliability, responsivness, assurance dan emphaty terhadap kepuasan jemaah adalah sebesar 0,620 atau $62 \%$. Hasil analisis tersebut menunjukan bahwa adanya pengaruh atau hubungan yang positif dan kuat tehadap kepuasan jemaah. Untuk perhitungan koefisien determinasi diperoleh nilai 0,720 atau $72 \%$, dapat disimpulkan bahwa $72 \%$ kepuasan jemaah dipengaruhi oleh pelayanan prima, sedangkan sisanya $28 \%$ dipengaruhi oleh faktor-faktor lain yang tidak penulis teliti.

Berdasarkan hasil penelitian yang telah diperoleh dan temuan yang telah dihasilkan, maka peneliti menyatakan beberapa hal dengan dharapan dapat memberikan kegunaan dan menjadi masukan bagi KBIH Al-Waritsah dalam hal pengoptimalan kualitas pelayanan terhadap jemaah. beberapa hal tersebut adalah sebagai berikut: a) $\mathrm{KBIH}$ Al-Waritsah hendaknya terus meningkatkan kualitas pelayanan, baik itu dari segi unsur tangibles, reability, responsiveness, assurance dan emphaty sehingga dapat menarik jemaah baru maupun jemaah lama untuk 
Hubungan Pelayanan Prima Kbih terhadap Kepuasan Jemaah Haji

bergabung pada KBIH Al-Waritsah. 1) KBIH Al-Waritsah hendaknya mempunyai standar pelayanan secara tertulis dan baku dalam hal ini agar para petugas/karyawan KBIH Al-Waritsah memiliki acuan mengenai mengapa, kapan, dengan siapa, dimana, dan bagaimana pelayanan mesti dilakukan (bagaimana memprlakukan jemaahnya). 2) Dalam menghadapi persaingan yang kompetitif dalam dunia perusahaan yang bergerak dalam bidang jasa, maka diharapkan "kepuasan pelanggan" dijadikan tujuan utama KBIH Al-Waritsah dalam memberikan pelayanan. b) Untuk peneliti yang akan datang disarankan untuk menambah variabel-variabel independen lainnya yang mempengaruhi kepuasaan jemaah haji.

\section{DAFTAR PUSTAKA}

Adya Barata, Atep. 2006. Dasar-dasar Pelayanan Prima. Jakarta: PT. Elex Media Komputindo.

Arikunto, Suharsimi. 2005. Manajemen Penelitian. Jakarta: Rineka Cipta.

Rahmayanty, Nina. 2013. Manajemen Pelayanan Prima. Yogyakarta: Graha Ilmu.

Ratminto \& Septi Winarsih Atik. 2014. Manajemen Pelayana. Yogyakarta: Pustaka Pelajar.

Saidah, Dewi. 2014. Metode penelitian dakwah: pendekatan kualitatif dan kuantitatif. Bandung: CV. Mimbar Pustaka.

Suprianto, J. 1997. Pengukuran Tingkat Kepuasan Pelanggan. Jakarta: Rienka Cipta.

Sutopo dan Suryanto Adi. 2009. Pelayanan Prima. Jakarta: LAN.

Tjiptono, Fandi. 2006. Manajemen Jasa. Yogyakarta: Andi.

Tjiptono, Fandi \& Anastasia Diana 2003. Total Quality Manajemen. Yogyakarta : Andi.

Riduwan M.B.A, 2012. Pengantar Statistika Sosial. Bandung: Alfabeta.

Sugiyono. 2012. Metode Penelitian Kuantitatif Kualitatif Dan R\&D. Bandung: Alfabeta

Philip Kotler \& Gery Amstrong. 1997. Dasar-Dasar Pemasaran, Edisi I dan II, Alih

Bahasa: Alexander Sindoro, Penyunting; Benyamin Molan. Jakarta : Pernhalindo.

KBIH Al-Waritsah, SOP KBIH Al-Waritsah

Departemen Agama RI. 2010, Petunjuk Teknis Pengorganisasian Kelompok Bimbingan Ibadah Haji. Jakarta: Direktorat Jendral Penyelenggaraan Haji dan Umroh

Kementrian agama RI. 2010, Petunjuk Pelaksanaan Akredetasi Kelompok Bimbingan Ibadah Haji. Jakarta: Direktorat Jendral Penyelenggaraan Haji dan Umroh 